OPEN ACCESS

Edited by:

Jinsong Bian,

National University of Singapore,

Singapore

Reviewed by:

Junbao Du,

Peking University First Hospital, China

YiChun Zhu,

Children's Hospital, Fudan University,

China

*Correspondence:

Ming Xian

mxian@wsu.edu

Specialty section:

This article was submitted to

Experimental Pharmacology and Drug

Discovery,

a section of the journa

Frontiers in Pharmacology

Received: 15 May 2017

Accepted: 26 June 2017

Published: 10 July 2017

Citation:

Kang J, Neill DL and Xian M (2017) Phosphonothioate-Based Hydrogen

Sulfide Releasing Reagents:

Chemistry and Biological

Applications.

Front. Pharmacol. 8:457.

doi: 10.3389/fphar.2017.00457

\section{Phosphonothioate-Based Hydrogen Sulfide Releasing Reagents: Chemistry and Biological Applications}

\author{
Jianming Kang, Deshka L. Neill and Ming Xian* \\ Department of Chemistry, Washington State University, Pullman, WA, United States
}

Hydrogen sulfide $\left(\mathrm{H}_{2} \mathrm{~S}\right)$ is a newly recognized gasotransmitter. Studies have demonstrated that the production of endogenous $\mathrm{H}_{2} \mathrm{~S}$ and the exogenous administration of $\mathrm{H}_{2} \mathrm{~S}$ can regulate many physiological and/or pathological processes. Therefore, $\mathrm{H}_{2} \mathrm{~S}$ releasing agents (also known as $\mathrm{H}_{2} \mathrm{~S}$ donors) are important research tools in advancing our understanding of the biology and clinical potential of $\mathrm{H}_{2} \mathrm{~S}$. Among currently available donors, GYY4137 is probably the most well-known and has been used in many studies in the past 10 years. Recently, a number of GYY4137 derivatives (e.g., phosphonothioate-based compounds) have been developed as $\mathrm{H}_{2} \mathrm{~S}$ donors. In this review, we summarize the development and application of these donors, which include Lawesson's reagent, substituted phosphorodithioates, cyclic phosphorane analogs, and $\mathrm{pH}$-controlled phosphonamidothioates (JK donors). These donors have advantages such as good water-solubility, slow and controllable $\mathrm{H}_{2} \mathrm{~S}$ release capability, and a variety of reported biological activities. However, it should be noted that the detailed $\mathrm{H}_{2} \mathrm{~S}$ release profiles and byproducts under real biological systems are still unclear for many of these donors. Only after we figure out these unknowns we will see better applications of these donors in $\mathrm{H}_{2} \mathrm{~S}$ research and therapy.

Keywords: hydrogen sulfide, $\mathrm{H}_{2} \mathrm{~S}$, donor, phosphonothiolate, $\mathrm{pH}$

\section{INTRODUCTION}

Hydrogen sulfide $\left(\mathrm{H}_{2} \mathrm{~S}\right)$ has traditionally been known as a poisonous gas, with the characteristic odor of rotten eggs. However, since 2000 it has also been recognized as an important cell signaling molecule, similar to nitric oxide (NO) and carbon monoxide (CO) ( $\mathrm{Li}$ and Moore, 2011; Olson, 2012; Wang, 2012; Kolluru et al., 2013). $\mathrm{H}_{2} \mathrm{~S}$ is now believed to be a mediator for many physiological and/or pathological processes such as inflammation, cancer, cardiovascular diseases, and oxidative stress (Kimura and Kimura, 2004; Calvert et al., 2010; Kimura et al., 2010; King and Lefer, 2011; Whiteman et al., 2011; Köhn et al., 2012; Predmore et al., 2012; Wang, 2012; Ariyaratnam et al., 2013; Jackson-Weaver et al., 2013; Wen et al., 2013; Lee et al., 2014; Szabo et al., 2014).

The enzymatic production of $\mathrm{H}_{2} \mathrm{~S}$ in mammalian systems has been attributed to at least three enzymes: cystathionine $\beta$-synthase (CBS), cystathionine $\gamma$-lyase (CSE), and 3-mercaptopyruvate sulfurtransferase (MPST) (Hu et al., 2011; Paul and Snyder, 2012; King, 2013; Banerjee, 2017). It is believed that $\mathrm{CBS}$ is the main $\mathrm{H}_{2} \mathrm{~S}$ synthase in the nervous system, whereas CSE plays the 
same role in most peripheral tissues, except for the liver and kidney, which contain both enzymes in substantial amounts. Enzyme-mediated $\mathrm{H}_{2} \mathrm{~S}$ production from sulfur-containing amino acids is summarized in Figure 1. Briefly, the condensation of two molecules of homocysteine by CSE generates homolanthionine and $\mathrm{H}_{2} \mathrm{~S}$. CSE can also catalyze the $\alpha-\gamma$-elimination of homocysteine to produce $\alpha$-ketobutyrate, ammonia, and $\mathrm{H}_{2} \mathrm{~S}$. CBS catalyzes the $\beta$-replacement of serine by homocysteine to form cystathionine, which can be further converted to cysteine, $\alpha$-ketobutyrate and ammonia by CSE. With cysteine as the key intermediate, both CBS and CSE can produce $\mathrm{H}_{2} \mathrm{~S}$ via $\beta$-replacement by homocysteine. In addition, CBS can swap cysteine for serine eliminating $\mathrm{H}_{2} \mathrm{~S}$ in the presence of water. Another route of CSE-catalyzed $\mathrm{H}_{2} \mathrm{~S}$ generation is via the $\alpha, \beta$ elimination of cysteine, to form pyruvate and ammonia. This is the major pathway for $\mathrm{H}_{2} \mathrm{~S}$ formation by CSE under physiologically relevant substrate concentrations. For CBS-catalyzed $\mathrm{H}_{2} \mathrm{~S}$ production, the $\beta$-replacement of cysteine by homocysteine is the dominant route. The third main pathway for $\mathrm{H}_{2} \mathrm{~S}$ production requires two enzymes, aspartate aminotransferase (AAT) and MPST. This pathway operates mainly in mitochondria (Whiteman et al., 2011). AAT catalyzes the transamination reaction between cysteine and $\alpha$-ketoglutarate to produce 3-mercaptopyruvate and glutamate, which in a subsequent step catalyzed by MPST liberates $\mathrm{H}_{2} \mathrm{~S}$ and pyruvate. In addition to these enzymatic pathways, $\mathrm{H}_{2} \mathrm{~S}$ can also be generated endogenously through the non-enzymatic reduction of elemental sulfur by reducing equivalents supplied through the glycolytic pathway (Kolluru et al., 2013).

The biological functions of $\mathrm{H}_{2} \mathrm{~S}$ may result from its reactions with biomolecules under physiological or pathological conditions. One of the most important molecular mechanisms of $\mathrm{H}_{2} \mathrm{~S}$ signaling is $S$-persulfidation, e.g., converting protein's thiols (-SH) to persulfides (-SSH) (Pan and Carroll, 2013; Paulsen and Carroll, 2013; Zhang et al., 2014). Many protein targets of S-persulfidation, including receptors, ion channels and enzymes, have been identified. This process is believed to be important as it provides a possible route by which $\mathrm{H}_{2} \mathrm{~S}$ alters the functions of a wider range of cellular proteins (Paul and Snyder, 2012; Vandiver et al., 2013; Yang et al., 2013). As for the mechanisms behind persulfidation, it is believed that $\mathrm{H}_{2} \mathrm{~S}$ can easily react with oxidized thiols such as sulfenic acids $(-\mathrm{SOH})$ or nitrosothiols (-SNO) to form persulfides (-SSH). It is also believed that $\mathrm{H}_{2} \mathrm{~S}$ can react with disulfides to form persulfides. However, the reactions of $\mathrm{H}_{2} \mathrm{~S}$ with disulfides, in particularly low molecular weight disulfides, are slow (Liu and Chang, 1987; Francoleon et al., 2011; Cuevasanta et al., 2015; Vasas et al., 2015). Protein environment may significantly enhance the reaction. For example, the reaction of $\mathrm{H}_{2} \mathrm{~S}$ with an active site disulfide in SQR is accelerated by $\sim 10^{6}$-fold with respect to free cystine (Jackson et al., 2012; Libiad et al., 2014; Mishanina et al., 2015). The concentration of disulfides in cytosol is usually low. Therefore the reaction between disulfides and $\mathrm{H}_{2} \mathrm{~S}$ is likely to be more significant in locations like endoplasmic reticulum or under oxidative conditions. Recent studies suggest that $\mathrm{H}_{2} \mathrm{~S}$ may interact with $\mathrm{NO}$ and related species. $\mathrm{H}_{2} \mathrm{~S}$ reacts with NO to form thionitrous acid (HSNO), which is the smallest
$S$-nitrosothiol, whose metabolites, including $\mathrm{NO}, \mathrm{NO}^{-}$, and $\mathrm{NO}^{++}$, have significant physiological functions (Filipovic et al., 2012b). $\mathrm{H}_{2} \mathrm{~S}$ can also act as a reductant and react with a number of one-electron and two-electron oxidants, such as hydroxyl radical $(\mathrm{HO})^{\bullet}$, nitrogen dioxide $\left(\mathrm{NO}_{2}\right)$, superoxide $\left(\mathrm{O}_{2}{ }^{\bullet-}\right)$, peroxynitrite $\left(\mathrm{ONOO}^{-}\right)$, and hydrogen peroxide $\left(\mathrm{H}_{2} \mathrm{O}_{2}\right)$ (Carballal et al., 2011; Filipovic et al., 2012a). Removal of these reactive oxygen species reduces intracellular redox imbalance, which is involved in the pathophysiology of a wide array of human diseases. Moreover, $\mathrm{H}_{2} \mathrm{~S}$ can easily react with metalloproteins, particularly heme-containing ones. The smaller size of $\mathrm{H}_{2} \mathrm{~S}$ compared to other low molecular weight thiols would make it more accessible to metal centers. Binding of $\mathrm{H}_{2} \mathrm{~S}$ to cytochrome c oxidase at moderately high $\mathrm{H}_{2} \mathrm{~S}$ concentrations is associated with the induction of the suspended animation state (Blackstone et al., 2005). Although $\mathrm{H}_{2} \mathrm{~S}$ inhibits cytochrome c oxidase, the situation is more complicated in tissues. At high concentrations, the mitochondria respiratory chain is inhibited. At low concentrations, $\mathrm{H}_{2} \mathrm{~S}$ stimulates oxygen consumption (Cooper and Brown, 2008). In addition, $\mathrm{H}_{2} \mathrm{~S}$ binds to hemoglobin forming ferric heme, which may be reduced by a second mole of $\mathrm{H}_{2} \mathrm{~S}$ to generate ferrous heme and hydrogen persulfide (Pietri et al., 2009). These intermediates may also be involved in some physiological/protective effects.

In the exploration of $\mathrm{H}_{2} \mathrm{~S}$ biology it is also important to explore the understudied chemistry and reactivity of $\mathrm{H}_{2} \mathrm{~S}$, and to be aware of the problems associated with the choice of resources used to produce $\mathrm{H}_{2} \mathrm{~S}$ in in vitro and in vivo experiments. So far, one of the main challenges in the $\mathrm{H}_{2} \mathrm{~S}$ field is precise delivery of $\mathrm{H}_{2} \mathrm{~S}$. Moreover, the ideal concentrations of $\mathrm{H}_{2} \mathrm{~S}$ in physiology and in therapy need to be better understood, because the therapeutic windows in almost all known pharmacological experiments for $\mathrm{H}_{2} \mathrm{~S}$ are very narrow. $\mathrm{H}_{2} \mathrm{~S}$ gas is the authentic resource with a volatile nature and unpleasant odor. Although $\mathrm{H}_{2} \mathrm{~S}$ gas has been used in many experiments, showing promising biological effects, it is far from ideal due to the difficulties in obtaining and maintaining constant concentrations, as well as the possible toxic effects of $\mathrm{H}_{2} \mathrm{~S}$ in excess (Blackstone et al., 2005; Blackstone and Roth, 2007; Collman et al., 2009; Xue et al., 2013). Inorganic sulfide salts, such as sodium sulfide $\left(\mathrm{Na}_{2} \mathrm{~S}\right)$ and sodium hydrogen sulfide (NaHS), are also widely used $\mathrm{H}_{2} \mathrm{~S}$ equivalents (Zhao et al., 2001; Zanardo et al., 2006; Zhang et al., 2013). These sulfide salts conveniently generate $\mathrm{H}_{2} \mathrm{~S}$, and no byproducts are produced after $\mathrm{H}_{2} \mathrm{~S}$ generation. However, these compounds are short-lived and un-controlled $\mathrm{H}_{2} \mathrm{~S}$ donors, as they release $\mathrm{H}_{2} \mathrm{~S}$ immediately once their solution is prepared. In addition, $\mathrm{H}_{2} \mathrm{~S}$ is very volatile in aqueous solution. DeLeon et al. (2012) have demonstrated that the half-life of $10 \mu \mathrm{M} \mathrm{Na}_{2} \mathrm{~S}$ solution is $0.5 \mathrm{~min}$ and no detectable $\mathrm{H}_{2} \mathrm{~S}$ is left after $12 \mathrm{~h}$. This uncontrollable and rapid release results in a spike of $\mathrm{H}_{2} \mathrm{~S}$ concentration that can cause severe damages in vivo. It should also be noted that commercial sulfide salts usually have different levels of impurities, which could affect experimental outcomes. With all these concerns, caution should be taken when using sulfide salts as $\mathrm{H}_{2} \mathrm{~S}$ donors.

Given the problems of $\mathrm{H}_{2} \mathrm{~S}$ gas and sulfide salts, synthetic and so-called 'controllable' $\mathrm{H}_{2} \mathrm{~S}$ donors have received considerable attention in recent years. So far, a number of donors have 


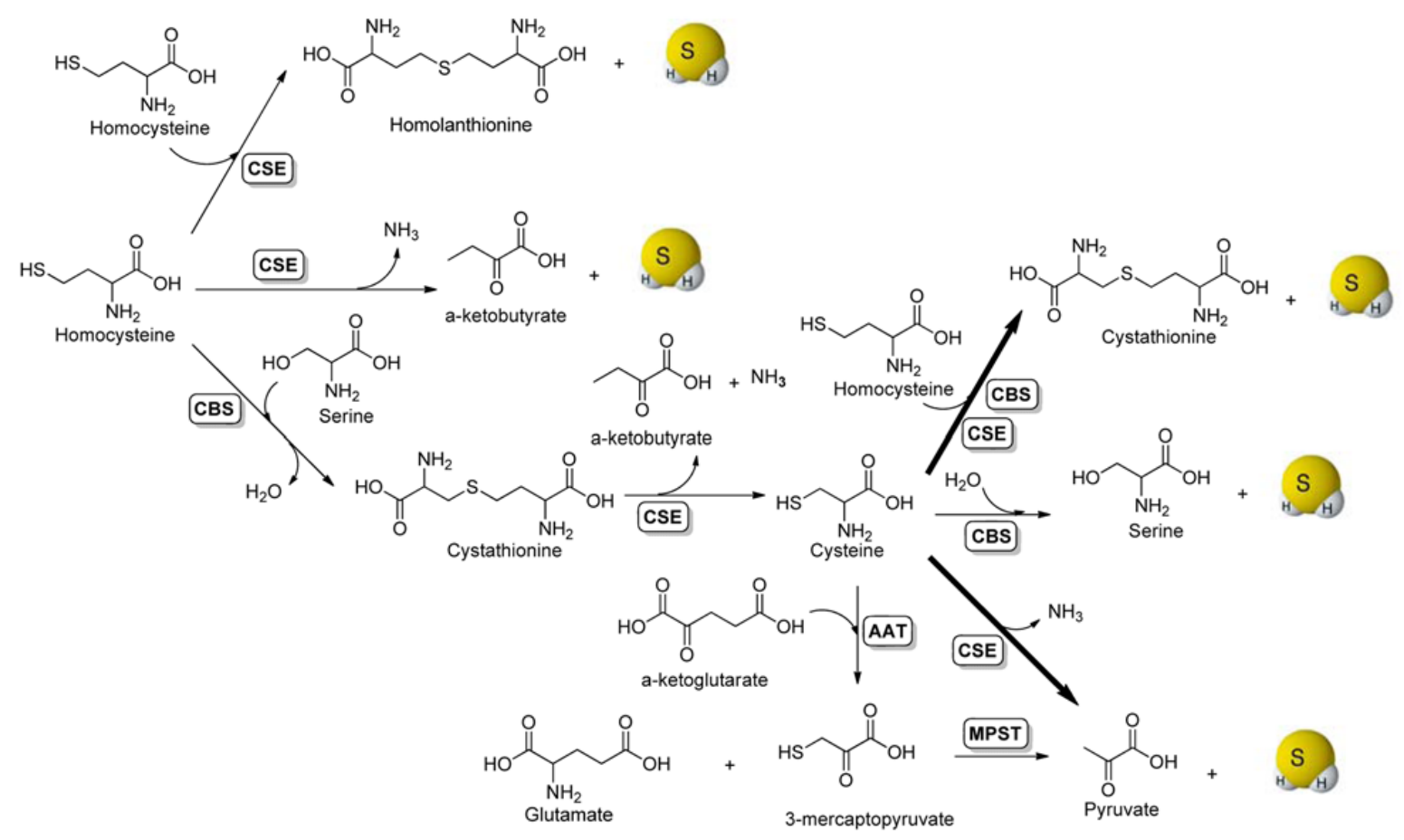

FIGURE 1 | Enzymatic production of $\mathrm{H}_{2} \mathrm{~S}$.

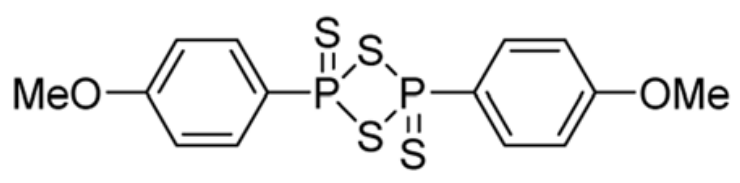

FIGURE 2 | Lawesson's reagent.

been developed and their $\mathrm{H}_{2} \mathrm{~S}$ releases are triggered by different mechanisms, such as hydrolysis, thiol activation, and photolysis (Li et al., 2008; Zhao et al., 2011, 2013, 2014, 2015; DevarieBaez et al., 2013; Fukushima et al., 2014; Zheng et al., 2017). Among all these synthetic donors, GYY4137 is the most widely used one and a variety of biological activities have been reported (Li et al., 2008). The core structure of GYY4137, i.e., phosphonothioate, represents a valuable template for the design of $\mathrm{H}_{2} \mathrm{~S}$ donors. In this review, we summarize the results of all known phosphonothioate-based $\mathrm{H}_{2} \mathrm{~S}$ donors in the context of their chemistry and biological activities.

\section{LAWESSON'S REAGENT}

Lawesson's reagent (2,4-bis(4-methoxyphenyl)-1,3,2,4dithiadiphosphetane-2,4-disulfide, Figure 2) is a sulfurization reagent often seen in organic synthesis (Ozturk et al., 2007). Its biological activity was largely unknown. With the increasing interest in $\mathrm{H}_{2} \mathrm{~S}$ biology, Lawesson's reagent was considered as an $\mathrm{H}_{2} \mathrm{~S}$ donor and some interesting activities have been reported.
In 2009, Lawesson's reagent was used as an $\mathrm{H}_{2} \mathrm{~S}$ equivalent to study the effects of $\mathrm{H}_{2} \mathrm{~S}$ on the inflammation and ulceration of the colon in a rat model of colitis (Wallace et al., 2009). Treatment with Lawesson's reagent and the standard NaHS resulted in a significant reduction in the severity of colitis, as measured by a decrease in colon thickness and reduced TNF- $\alpha$ mRNA expression, a proinflammatory cytokine. Also Medeiros et al. (2009) found that Lawesson's reagent could prevent ethanol-induced gastric damage in a dose-dependent manner and the primary mechanism was believed to be the activation of $\mathrm{K}_{\mathrm{ATP}}$ channels and afferent neurons/TRPV1 receptors. Nicolau et al. (2013) reported that Lawesson's reagent exhibited $\mathrm{H}_{2} \mathrm{~S}$-relavent protective effects on gastric damage, induced by alendronate (ALD)-a bisphosphonate drug for the prevention and treatment of bone diseases. It was also found that the blockade of $\mathrm{K}_{\mathrm{ATP}}$ channels alone reversed Lawesson's reagent's protective effects against ALD-induced gastric damage, suggesting an involvement of $\mathrm{K}_{\mathrm{ATP}}$ channels in $\mathrm{H}_{2} \mathrm{~S}$ gastroprotective effects. It should be noted that the $\mathrm{H}_{2} \mathrm{~S}$ releasing mechanism of Lawesson's reagent is thought to be due to spontaneous hydrolysis. However, the hydrolysis kinetics and by-products are still unclear. Moreover, the poor solubility of Lawesson's reagent in physiological solutions limits its applications.

\section{GYY4137}

GYY4137, or morpholin-4-ium 4 methoxyphenyl(morpholino) phosphinodithioate, is a Lawesson's reagent derivative and 


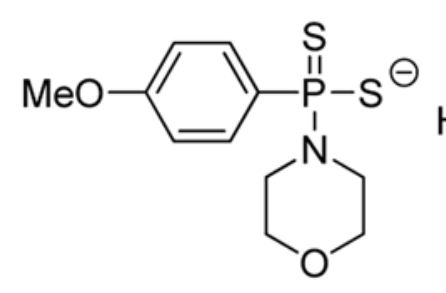

GYY4137

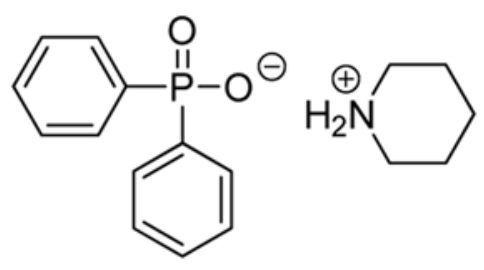

ZYJ1122

FIGURE 3 | The structure of GYY4137 and its control compound.


FIGURE 4 | O-Substituted phosphorodithioates.

can be easily prepared by reacting Lawesson's reagent with morpholine (Li et al., 2008) (Figure 3). GYY4137 is one of the first organic small molecule $\mathrm{H}_{2} \mathrm{~S}$ donors reported. This compound has excellent water solubility and is believed to release $\mathrm{H}_{2} \mathrm{~S}$ very slowly under physiological conditions. $\mathrm{H}_{2} \mathrm{~S}$ release from GYY4137 was also found to be $\mathrm{pH}$ and temperature dependent, with a less release at lower temperatures like $4^{\circ} \mathrm{C}$ and a greater release at acidic $\mathrm{pH}$ like $\mathrm{pH} 3.0$ (Li et al., 2008).

Unlike commonly used sulfide salts such as $\mathrm{Na}_{2} \mathrm{~S}$ and $\mathrm{NaHS}$, which release $\mathrm{H}_{2} \mathrm{~S}$ instantaneously upon dissolving in aqueous solutions, $\mathrm{H}_{2} \mathrm{~S}$ release from GYY4137 is at a sustained rate and remains at a low level, even after several days (measured in buffers) (Li et al., 2008). When administrated into animals, GYY4137 can cause and maintain elevated $\mathrm{H}_{2} \mathrm{~S}$ levels for a long period of time. For example, after intravenous or intraperitoneal administration of GYY4137 $(133 \mu \mathrm{mol} / \mathrm{kg})$ to Sprague-Dawley rats, plasma $\mathrm{H}_{2} \mathrm{~S}$ concentration was increased at $30 \mathrm{~min}$ and remained elevated over the 180 -min time course.

GYY4137 is a very popular $\mathrm{H}_{2} \mathrm{~S}$ donor and many researchers have used it to study the functions of $\mathrm{H}_{2} \mathrm{~S}$. A variety of $\mathrm{H}_{2} \mathrm{~S}$ relavent activities have been reported. In the original paper that reported the discovery of GYY4137 (Li et al., 2008), it was found that isolated blood vessels respond to the presence of GYY4137 $(200 \mu \mathrm{M})$ with a slowly developing $(\sim 10 \mathrm{~min})$ but sustained $(\sim 40 \mathrm{~min})$ vasorelaxation while NaHS $(300 \mu \mathrm{M})$ caused rapid, transient, and reversible ( $\sim 20$ to 30 s) relaxation of aortic rings.
GYY4137 (26.6-133 $\mu \mathrm{mol} / \mathrm{kg}$ ) showed a slow (at $30 \mathrm{~min}$ ) drop in blood pressure while NaHS $(2.5-20 \mu \mathrm{mol} / \mathrm{kg})$ caused fast (10-30 s) and dose-related decrease in blood pressure. GYY4137 has also been shown to exert cytoprotective effects under different pathological conditions. In a report by Fox et al. (2012) GYY4137 (10-200 $\mu \mathrm{M})$ treatment significantly inhibited oxidative stressinduced mitochondrial dysfunction and cell death through pathways involving Akt/PI3K-dependent signaling in human mesenchymal progenitor cells and human articular chondrocytes. In contrast, cell death increased with the pharmacological inhibition of $\mathrm{H}_{2} \mathrm{~S}$ synthesis or by CBS/CSE-siRNA treatment. In another study, Wei et al. (2014) demonstrated that GYY4137 (100 and $200 \mu \mathrm{M}$ ) protects against high glucose-induced cytotoxicity by activation of the AMPK/mTOR signaling pathway in $\mathrm{H} 9 \mathrm{c} 2$ myocardial cells. In vivo cytoprotection was carried out in a hyperoxia-induced lung injury model in new born rat pups by Vadivel et al. (2014). Intraperitoneal administration of GYY4137 $(37.75 \mathrm{mg} / \mathrm{kg} /$ day) preserved and restored normal alveolar growth, attenuated pulmonary hypertension, and prevented pulmonary artery smooth muscle cell proliferation in rat pups exposed to hyperoxia.

GYY4137 has also been used in cellular and in vivo models to study $\mathrm{H}_{2} \mathrm{~S}$ 's anti-inflammatory effects. Whiteman et al. (2010) showed that in murine RAW 264.7 macrophages, pretreatment with GYY4137 (50-200 $\mu \mathrm{M})$ significantly and concentration-dependently inhibits LPS-induced release of proinflammatory mediators such as IL-1b, IL-6, TNF- $\alpha$, NO, and PGE2. It also increased the synthesis of the anti-inflammatory 

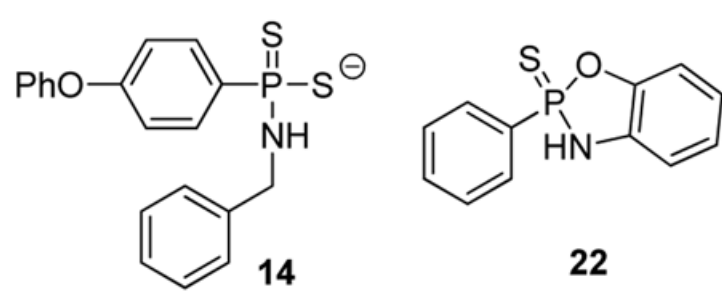

22
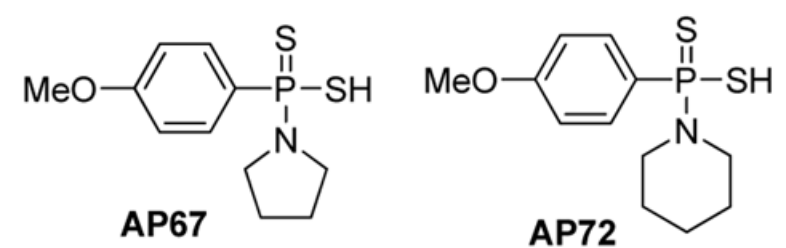

FIGURE 5 | Structures of representative GYY4137 analogs.

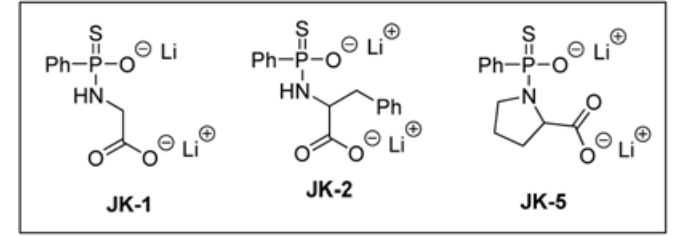

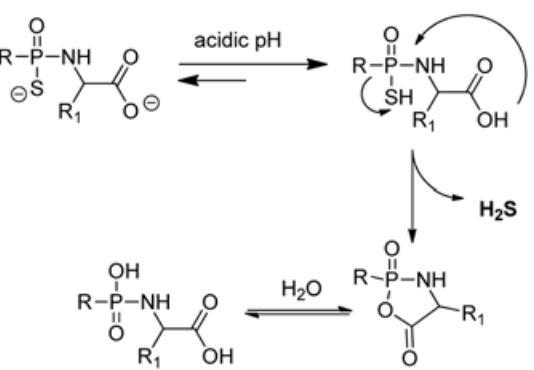

FIGURE 6 | The structures of selected JK donors and the $\mathrm{H}_{2} \mathrm{~S}$ release mechanism.

chemokine IL-10 through NF-кB/ATF-2/HSP-27-dependent pathways. In contrast, NaHS exhibited a biphasic effect on proinflammatory mediators and, at high concentrations (>200 $\mu \mathrm{M})$, increased the synthesis of pro-inflammatory mediators. Burguera et al. (2014) evaluated the effects of NaHS and GYY4137 on inflammation in articular chondrocytes. Both NaHS and GYY4137 led to significantly reduced NO, PGE-2, IL-6 and MMP13, which was achieved by downregulation of NOS2, cyclooxigenase-2 (COX2), prostaglandin E synthase (PTGES), IL-6 and MMP13 through NF-кB inhibition. GYY4137 has also been shown to be anti-inflammatory in vivo. In a report by $\mathrm{Li}$ et al. (2009), the intraperitoneal administration of GYY4137 (50 $\mathrm{mg} / \mathrm{kg}$ ) to conscious rats after LPS decreased the subsequent increase in plasma pro-inflammatory cytokines (TNF- $\alpha$, IL-1 $\beta$, IL-6) via the suppression of NF- $\kappa B$ activity. GYY4137 administration also decreased the LPS-induced increase in lung myeloperoxidase activity, elevated anti-inflammatory cytokine IL-10 concentration in plasma, and reduced tissue inflammation, although the mechanism is still not clear. Wu et al. (2015) showed that in Coxsackie virus B3 (CVB3)-infected rat cardiomyocytes, GYY4137 suppressed CVB3-induced secretion of $\mathrm{LDH}, \mathrm{CK}-\mathrm{MB}$ and pro-inflammatory cytokines, such as tumor necrosis factor- $\alpha$, interleukin (IL)-1 $\beta$ and IL-6. They hypothesized that the mechanism may be associated with the suppression of NF- $\kappa \mathrm{B}$ and MAPK signaling pathway activation.

It was proposed that low (endogenous) $\mathrm{H}_{2} \mathrm{~S}$ concentrations tend to promote, while high (exogenous) $\mathrm{H}_{2} \mathrm{~S}$ concentrations tend to inhibit cancer cell proliferation (Hellmich and Szabo, 2015). The anti-cancer activity of GYY4137 was first reported by Lee et al. (2011) in both in vitro and in vivo models. In this study, GYY4137 (100 $\mu \mathrm{M}$ to $1 \mathrm{mM}$ ) caused concentration-dependent $\mathrm{G}_{2} / \mathrm{M}$ phase cell cycle arrest and PARP-/caspase-9-dependent apoptosis of seven different human cancer cell lines (HeLa, HCT-116, HepG2, HL-60, MCF-7, MV4-11 and U2OS) but did not affect normal human lung fibroblasts (IMR90, WI-38) suggesting that cancer cells can be killed selectively. Interestingly NaHS was less potent and not active, and ZYJ1122 (Figure 3), a sulfur lacking control compound, was also inactive. These control results suggest that the anti-cancer effects were due to sustained exposure to low levels of $\mathrm{H}_{2} \mathrm{~S}$. For in vivo experiments, the intraperitoneal administration of GYY4137 (100-300 mg/kg/day) significantly reduced tumor growth in HL-60 and MV4-11. Lu et al. (2014) reported that GYY4137 (10-50 mg/kg) significantly inhibited tumor growth in the subcutaneous HepG2 xenograft mice model, possibly by suppression of STAT3 activation. Recently GYY4137 was found to show interesting activity against virus infection for respiratory syncytial virus, human metapneumovirus, and Nipah virus (Li et al., 2015). GYY4137 treatment showed no effect on viral genome replication or viral mRNA/protein synthesis. However, it inhibits syncytium formation and virus assembly/release. In this study, the concentrations of GYY4137 applied were quite high (up to $10 \mathrm{mM}$ ).

So far GYY4137 has been widely used in $\mathrm{H}_{2} \mathrm{~S}$ research and is now considered a standard $\mathrm{H}_{2} \mathrm{~S}$ donor. However, caution should be taken in choosing GYY4137 in studies. Normally, $\mathrm{H}_{2} \mathrm{~S}$ levels before and after GYY4137 administration should be validated. Due to its fixed and very slow $\mathrm{H}_{2} \mathrm{~S}$ release capability, high concentrations (up to $\mathrm{mM}$ levels) are often required to accumulate enough $\mathrm{H}_{2} \mathrm{~S}$ for biological studies. Such concentrations are not therapeutically preferred. In addition, the mechanism of $\mathrm{H}_{2} \mathrm{~S}$ release from GYY4137 is still unclear. It was proposed to be hydrolysis based, but the 
TABLE 1 | Key information of representative phosphonothioate-type donors.

\begin{tabular}{|c|c|c|c|}
\hline Donors & Structures & $\begin{array}{l}\text { Chemical/physical } \\
\text { properties }\end{array}$ & Biological activities \\
\hline Lawesson's reagent & & $\begin{array}{l}\text { Water insoluble, DMSO } \\
\text { soluble, Very slow } \mathrm{H}_{2} \mathrm{~S} \\
\text { release }\end{array}$ & $\begin{array}{l}\text { Anti-inflammatory, } \\
\text { protective effects } \\
\text { against gastric injuries, } \\
\text { ion channel regulation }\end{array}$ \\
\hline GYY4137 & & $\begin{array}{l}\text { Water soluble, very } \\
\text { slow } \mathrm{H}_{2} \mathrm{~S} \text { release }\end{array}$ & $\begin{array}{l}\text { Cytoprotection, } \\
\text { vasorelaxation, } \\
\text { anti-inflammatory, } \\
\text { anti-cancer }\end{array}$ \\
\hline O-substituted phosphorodithioates & & $\begin{array}{l}\text { Water soluble, very } \\
\text { slow } \mathrm{H}_{2} \mathrm{~S} \text { release }\end{array}$ & $\begin{array}{l}\text { Protective effects } \\
\text { against oxidative } \\
\text { damage }\end{array}$ \\
\hline Cyclic phosphorane & & $\begin{array}{l}\text { Water insoluble; DMSO } \\
\text { soluble, slow } \mathrm{H}_{2} \mathrm{~S} \\
\text { release }\end{array}$ & Anti-cancer \\
\hline Protonated GYY4137 analogs & & $\begin{array}{l}\text { Water soluble, very } \\
\text { slow } \mathrm{H}_{2} \mathrm{~S} \text { release }\end{array}$ & Vasorelaxation \\
\hline JK donors & $\begin{array}{r}\mathrm{Ph}- \\
\mathrm{H}\end{array}$ & $\begin{array}{l}\text { Water soluble, } \mathrm{H}_{2} \mathrm{~S} \\
\text { release controllable, } \\
\text { regulated by } \mathrm{pH}\end{array}$ & $\begin{array}{l}\text { Protective effects in } \\
\mathrm{Ml} / \mathrm{R} \text { and gastric } \\
\text { mucosal injury }\end{array}$ \\
\hline
\end{tabular}

kinetics and decomposition intermediate/final product have not been well characterized. In biological systems, GYY4137 may interact with certain biomolecules to facilitate $\mathrm{H}_{2} \mathrm{~S}$ release while the identity of those molecules is unclear. In this regard, appropriate control experiments should be carried out. Recently ZYJ1122 was used as a control compound. However, given its different structure from GYY4137, whether or not it is a suitable control compound is still uncertain.

\section{GYY4137 ANALOGS}

Given the fixed $\mathrm{H}_{2}$ S-release capability of GYY4137, researchers have tried to modify its structure with the hope of changing the donor's $\mathrm{H}_{2} \mathrm{~S}$ release profile. Park et al. (2013) prepared a series of $\mathrm{O}$-aryl- and alkyl-substituted phosphorodithioates by replacing the phenyl-phosphorus linkage of GYY4137 with an oxygen-phosphorus bond (such as $\mathbf{5 a}, \mathbf{5 b}$, Figure 4). It was found that $O$-aryl-substituted analogs showed similar slow and sustainable $\mathrm{H}_{2} \mathrm{~S}$ generation as GYY4137, while O-alkylsubstituted analogs only showed trace amount of $\mathrm{H}_{2} \mathrm{~S}$ release. It was hypothesized that $O$-alkyl substitutions increased the stability of phosphorodithioates and therefore decreased the efficiency of hydrolysis to produce $\mathrm{H}_{2} \mathrm{~S}$. These donors showed some protective activity against $\mathrm{H}_{2} \mathrm{O}_{2}$-induced oxidative damage in $\mathrm{H} 9 \mathrm{c} 2$ cells as well.
Feng et al. (2015) synthesized a series of GYY4137 analogs with different $\mathrm{H}_{2} \mathrm{~S}$ releasing rates, and tested their anti-proliferative activity against several solid tumor cell lines. Two representative donors $\mathbf{1 4}$ and $\mathbf{2 2}$ are shown in Figure 5. To validate $\mathrm{H}_{2} \mathrm{~S}$ production from the donors, confocal imaging using a fluorescent probe was employed to quantify intracellular $\mathrm{H}_{2} \mathrm{~S}$. Intracellular $\mathrm{pH}$ ( $\mathrm{pHi}$ ) was also used as an alternative indicator for intracellular $\mathrm{H}_{2} \mathrm{~S}$, because a decreased pHi should be due to increased glycolysis, causing overproduction of lactic acid and decreased anion and $\mathrm{Na} / \mathrm{H}$ exchange activity, thus introducing intracellular acidification. At $50 \mu \mathrm{M}, 14$ reduced pHi to 6.75 while GYY4137 reduced $\mathrm{pHi}$ to 7.14 , indicating that 14 released more $\mathrm{H}_{2} \mathrm{~S}$ than GYY4137. Confocal imaging also confirmed better $\mathrm{H}_{2} \mathrm{~S}$ releasing ability of $\mathbf{1 4}$ compared to GYY4137. At $200 \mu \mathrm{M}$, 14 released $41.5 \mu \mathrm{M} \mathrm{H} \mathrm{H}_{2} \mathrm{~S}$ in MCF7 cells at $6 \mathrm{~h}$ but GYY4137 released only $5.41 \mu \mathrm{M}$. Greater cell permeability of $\mathbf{1 4}$ was believed to be a key factor for its improved intracellular $\mathrm{H}_{2} \mathrm{~S}$ releasing ability. The authors also explored a series of 2,3dihydro-2-phenyl-2-sulfanylenebenzo[d][1,3,2] oxazaphospholes by cyclizing these initial structures. They proposed that cyclization may lead to more control over the reactivity due to limited conformational freedom. Compound 22 was shown to have the best $\mathrm{H}_{2} \mathrm{~S}$ releasing capacity and 22 was also the most potent compound against MCF7 $\left(\mathrm{IC}_{50}=5.7 \mu \mathrm{M}\right)$ and SKOV3 $\left(\mathrm{IC}_{50}=6.12 \mu \mathrm{M}\right)$ cell lines. From all compounds studied in this work, 22 was the safest 
compound with an improved therapeutic window of over eightfold in WI38 ( $\left.\mathrm{IC}_{50}>50 \mu \mathrm{M}\right)$ cells. At $100 \mu \mathrm{M}, 22$ inhibited MCF7 spheroid growth by nearly $70 \%$ after 14 days which further characterized its anticancer activity. Mechanism study showed an increase in cleaved poly (ADP-ribose) polymerase (PARP) and activated caspase-7 in MCF7 cells, indicating that the mechanism of cancer cell death was apoptosis.

Protonated GYY4137 analogs such as AP67 and AP72 have also been prepared and studied (Chitnis et al., 2013). These compounds likely undergo ionization to form their corresponding salts under physiological pH. AP67 and AP72 have shown potent vasodilatory effects on precontracted bovine posterior ciliary arteries (PCAs) through endogenous NO synthesis and the activation of $\mathrm{K}_{\mathrm{ATP}}$ channels. Further activities for these interesting donors are still to be discovered.

\section{pH-DEPENDENT PHOSPHONAMIDOTHIOATE-BASED DONORS (JK DONORS)}

$\mathrm{H}_{2} \mathrm{~S}$ release from GYY4137 and related phosphonothioate donors is suggested to be hydrolysis based. However, these donors' $\mathrm{H}_{2} \mathrm{~S}$ production in aqueous buffers was found to be very slow, suggesting that the intermolecular hydrolysis reaction with water is quite slow. While this very slow $\mathrm{H}_{2} \mathrm{~S}$ release is not necessarily a problem, it would be ideal to also have access to faster release donors, so that researchers would have more options. With this idea in mind, Kang et al. (2016) reported a series of phosphonamidothioate-based donors (e.g., JK donors), which showed enhanced $\mathrm{H}_{2} \mathrm{~S}$ releasing capabilities.

As shown in Figure 6, these donors contain a free carboxylate group adjacent to the phosphonamidothioate core. Under neutral or slightly acidic $\mathrm{pH}$, JKs are expected to be protonated to form phosphorothioates. Then, the nucleophilic carboxylate can attack the phosphorothioate center to push $\mathrm{H}_{2} \mathrm{~S}$ away and form a fivemembered-ring intermediate (or its hydrolyzed product). This cyclization process is believed to contribute to the enhancement of $\mathrm{H}_{2} \mathrm{~S}$ release. In this study, the release of $\mathrm{H}_{2} \mathrm{~S}$ from these donors was tested using a modified zinc sulfide-precipitationbased methylene blue (MB) method, because the standard MB method utilizes strongly acidic conditions which can cause false signals. As expected, JK donors showed a more enhanced $\mathrm{H}_{2} \mathrm{~S}$ release than GYY4137. Most interestingly, the $\mathrm{H}_{2} \mathrm{~S}$ release from JKs was found to be very $\mathrm{pH}$-dependent, with a faster and more $\mathrm{H}_{2} \mathrm{~S}$ release under acidic $\mathrm{pH}$ and a slower and less abundant $\mathrm{H}_{2} \mathrm{~S}$ release at neutral or basic $\mathrm{pH}$. Moreover, structural modifications could also affect $\mathrm{H}_{2} \mathrm{~S}$ release. For example, JK-1 releases barely detectable $\mathrm{H}_{2} \mathrm{~S}$ at $\mathrm{pH} 7.4$ and 8, but significant amounts of $\mathrm{H}_{2} \mathrm{~S}$ at $\mathrm{pH} 5$ or 6 . The introduction of a benzyl group at the $\alpha$-position makes the donor, JK-2, release obviously detectable $\mathrm{H}_{2} \mathrm{~S}$ even under neutral or weak basic $\mathrm{pH}$. JK-5, on the other hand, showed no $\mathrm{H}_{2} \mathrm{~S}$ release at all, presumably the rigid proline ring inhibits intramolecular cyclization.
A pH decrease under pathological conditions, such as cancer and ischemia/reperfusion injuries are known. As such, JK donors are expected to be useful tools for the study of $\mathrm{H}_{2} \mathrm{~S}$ and its role under those pathological conditions. Indeed, the cytoprotective effects of JK-1 and JK-2 on a cellular model of myocardial ischemia/reperfusion (MI/R) injury were demonstrated. These donors also showed significant protection in a murine model of $\mathrm{MI} / \mathrm{R}$ injury (induced by subjecting mice to $45 \mathrm{~min}$ of left ventricular ischemia, followed by $24 \mathrm{~h}$ of reperfusion). Compared to vehicle-treated mice, mice treated with donors showed significantly reduced infarct size per area-at-risk (INF/AAR). The protective effects were also validated by measuring circulating cardiac troponin I levels, the marker for acute myocardial infarction. Troponin I levels were significantly reduced with JK-1 or JK-2 treatment.

Recently, some other $\mathrm{H}_{2} \mathrm{~S}$-relevant activities of $\mathrm{JK}$ donors have been revealed. In one example, Wu et al. (2016) developed a JK-1 based nanofiber, PCL-JK1, through electrospinning of polycaprolactone (PCL) containing JK-1. Compared to JK-1, PCL-JK1 showed a similar $\mathrm{pH}$ regulated $\mathrm{H}_{2} \mathrm{~S}$ releasing behavior. However, $\mathrm{H}_{2} \mathrm{~S}$ release was prolonged by the fibrous matrix as demonstrated by slower releasing rates. Cell-compatibility was carried out using NIH 3T3 fibroblast cells and no cytotoxicity was observed at both $\mathrm{pH} 6.0$ and $\mathrm{pH} 7.4$ upon culturing for $72 \mathrm{~h}$. The use of PCL-JK1 as a wound dressing agent toward a cutaneous wound model was tested. PCL-JK1 was found to significantly enhance the wound repair and regeneration efficiency compared with PCL fiber alone, likely due to the ability of $\mathrm{H}_{2} \mathrm{~S}$ to inhibit inflammation, reduce oxidative damage and increase angiogenesis. In another example, Yang et al. (2017) demonstrated that the intragastrical (IG) pre-administration of $\mathrm{JK}-1$ protects gastric mucosa from aspirin (ASP)-induced gastric mucosal injury in vivo. Preconditioning with JK-1 alleviated ASPinduced inflammation response which was further validated by decreased levels of pro-inflammatory factors IL- 6 and TNF- $\alpha$. JK-1 was also shown to blunt ASP-induced oxidative stress evidenced by reduced MPO levels in gastric tissues. In vitro cellular experiments suggested that the exposure of gastric mucosal epithelial (GES-1) cells to $\mathrm{HClO}$, imitating MPO-driven oxidative injury, decreased cell viability, increased apoptotic rate and damaged mitochondrial function, which were reversed by pretreatment with JK-1.

\section{CONCLUSION}

GYY4137 and related analogs have been widely used in $\mathrm{H}_{2} \mathrm{~S}$ studies due to their excellent solubility and slow $\mathrm{H}_{2} \mathrm{~S}$ release capability. A summary of key information of some representative donors in this category is shown in Table 1. Current results suggest the phosphorothioate structure is a valuable template for the design of $\mathrm{H}_{2} \mathrm{~S}$ donors. Structural modifications on the core structure can lead to donors with varied and controllable $\mathrm{H}_{2} \mathrm{~S}$ release ability. It should be noted that their $\mathrm{H}_{2} \mathrm{~S}$ release profiles in simple systems such as aqueous buffers are usually available. However, information of their release (kinetics, mechanism, intermediates, byproducts, etc.) in real biological systems (cells, 
tissues, etc.) is difficult to obtain. This lack of information can be a problem. In some cases it is uncertain if the observed activities are due to $\mathrm{H}_{2} \mathrm{~S}$, or the donor molecule itself, or the decomposed by-product(s). Phosphorodithioates are likely to be biologically active molecules. In order to use GYY4137 type molecules as $\mathrm{H}_{2} \mathrm{~S}$ donors, one has to clearly understand the mechanism and profiles of $\mathrm{H}_{2} \mathrm{~S}$ release from these molecules, as well as the identity of the by-products. Only with this knowledge available can appropriate control experiments be designed and carried out.

\section{REFERENCES}

Ariyaratnam, P., Loubani, M., and Morice, A. H. (2013). Hydrogen sulphide vasodilates human pulmonary arteries: a possible role in pulmonary hypertension? Microvasc. Res. 90, 135-137. doi: 10.1016/j.mvr.2013.09.002

Banerjee, R. (2017). Catalytic promiscuity and heme-dependent redox regulation of $\mathrm{H}_{2} \mathrm{~S}$ synthesis. Curr. Opin. Chem. Biol. 37, 115-121. doi: 10.1016/j.cbpa.2017. 02.021

Blackstone, E., Morrison, M., and Roth, M. B. (2005). $\mathrm{H}_{2} \mathrm{~S}$ induces a suspended animation-like state in mice. Science 308, 518. doi: 10.1126/science. 1108581

Blackstone, E., and Roth, M. B. (2007). Suspended animation-like state protects mice from lethal hypoxia. Shock 27, 370-372. doi: 10.1097/SHK. $0 \mathrm{~b} 013 \mathrm{e} 31802 \mathrm{e} 27 \mathrm{a} 0$

Burguera, E. F., Vela-Anero, A., Magalhaes, J., Meijide-Failde, R., and Blanco, F. J. (2014). Effect of hydrogen sulfide sources on inflammation and catabolic markers on interleukin 1beta-stimulated human articular chondrocytes. Osteoarthritis Cartilage 22, 1026-1035. doi: 10.1016/j.joca.2014.04.031

Calvert, J. W., Coetzee, W. A., and Lefer, D. J. (2010). Novel insights into hydrogen sulfide-mediated cytoprotection. Antioxid. Redox Signal. 12, 1203-1217. doi: 10.1089 /ars.2009.2882

Carballal, S., Trujillo, M., Cuevasanta, E., Bartesaghi, S., Moller, M. N., Folkes, L. K., et al. (2011). Reactivity of hydrogen sulfide with peroxynitrite and other oxidants of biological interest. Free Radic. Biol. Med. 50, 196-205. doi: 10.1016/ j.freeradbiomed.2010.10.705

Chitnis, M. K., Njie-Mbye, Y. F., Opere, C. A., Wood, M. E., Whiteman, M., and Ohia, S. E. (2013). Pharmacological actions of the slow release hydrogen sulfide donor GYY4137 on phenylephrine-induced tone in isolated bovine ciliary artery. Exp. Eye Res. 116, 350-354. doi: 10.1016/j.exer.2013.10.004

Collman, J. P., Ghosh, S., Dey, A., and Decréau, R. A. (2009). Using a functional enzyme model to understand the chemistry behind hydrogen sulfide induced hibernation. Proc. Natl. Acad. Sci. U.S.A. 106, 22090-22095. doi: 10.1073/pnas. 0904082106

Cooper, C. E., and Brown, G. C. (2008). The inhibition of mitochondrial cytochrome oxidase by the gases carbon monoxide, nitric oxide, hydrogen cyanide and hydrogen sulfide: chemical mechanism and physiological significance. J. Bioenerg. Biomembr. 40, 533-539. doi: 10.1007/s10863-0089166-6

Cuevasanta, E., Lange, M., Bonanata, J., Coitiño, E. L., Ferrer-Sueta, G., Filipovic, M. R., et al. (2015). Reaction of hydrogen sulfide with disulfide and sulfenic acid to form the strongly nucleophilic persulfide. J. Biol. Chem. 290, 26866-26880. doi: $10.1074 /$ jbc.M115.672816

DeLeon, E. R., Stoy, G. F., and Olson, K. R. (2012). Passive loss of hydrogen sulfide in biological experiments. Anal. Biochem. 421, 203-207. doi: 10.1016/j.ab.2011. 10.016

Devarie-Baez, N. O., Bagdon, P. E., Peng, B., Zhao, Y., Park, C. M., and Xian, M. (2013). Light-induced hydrogen sulfide release from "caged" gem-dithiols. Org. Lett. 15, 2786-2789. doi: 10.1021/ol401118k

Feng, W., Teo, X. Y., Novera, W., Ramanujulu, P. M., Liang, D., Huang, D., et al. (2015). Discovery of new $\mathrm{H}_{2} \mathrm{~S}$ releasing phosphordithioates and 2,3-Dihydro-2-phenyl-2-sulfanylenebenzo[ $d][1,3,2]$ oxazaphospholes with improved antiproliferative activity. J. Med. Chem. 58, 6456-6480. doi: 10.1021/acs.jmedchem.5b00848

Filipovic, M. R., Miljkovic, J., Allgauer, A., Chaurio, R., Shubina, T., Herrmann, M., et al. (2012a). Biochemical insight into physiological effects of $\mathrm{H}_{2} \mathrm{~S}$; reaction

\section{AUTHOR CONTRIBUTIONS}

$\mathrm{JK}$ and $\mathrm{DN}$ collected and analyzed references. JK, DN, and MX wrote the article. All authors listed have made substantial contribution to the work and approved it for publication.

\section{FUNDING}

This work was supported by the NIH (R01HL116571).

with peroxynitrite and formation of a new nitric oxide donor, sulfinyl nitrite. Biochem. J. 441, 609-621. doi: 10.1042/BJ20111389

Filipovic, M. R., Miljkovic, J. L., Nauser, T., Royzen, M., Klos, K., Shubina, T., et al. (2012b). Chemical characterization of the smallest S-nitrosothiol, HSNO; cellular cross-talk of $\mathrm{H}_{2} \mathrm{~S}$ and S-nitrosothiols. J. Am. Chem. Soc. 134, 12016-12027. doi: 10.1021/ja3009693

Fox, B., Schantz, J. T., Haigh, R., Wood, M. E., Moore, P. K., Viner, N., et al. (2012). Inducible hydrogen sulfide synthesis in chondrocytes and mesenchymal progenitor cells: is $\mathrm{H}_{2} \mathrm{~S}$ a novel cytoprotective mediator in the inflamed joint? J. Cell. Mol. Med. 16, 896-910. doi: 10.1111/j.1582-4934.2011.01357.x

Francoleon, N. E., Carrington, S. J., and Fukuto, J. M. (2011). The reaction of $\mathrm{H}_{2} \mathrm{~S}$ with oxidized thiols: generation of persulfides and implications to $\mathrm{H}_{2} \mathrm{~S}$ biology. Arch. Biochem. Biophys. 516, 146-153. doi: 10.1016/j.abb.2011.09.015

Fukushima, N., Ieda, N., Sasakura, K., Nagano, T., Hanaoka, K., Suzuki, T., et al. (2014). Synthesis of a photocontrollable hydrogen sulfide donor using ketoprofenate photocages. Chem. Commun. 50, 587-589. doi: 10.1039/ c3cc47421f

Hellmich, M. R., and Szabo, C. (2015). Hydrogen sulfide and cancer. Handb. Exp. Pharmacol. 230, 233-241. doi: 10.1007/978-3-319-18144-8_12

Hu, L. F., Lu, M., Hon Wong, P. T., and Bian, J. S. (2011). Hydrogen sulfide: neurophysiology and neuropathology. Antioxid. Redox Signal. 15, 405-419. doi: 10.1089/ars.2010.3517

Jackson, M. R., Melideo, S. L., and Jorns, M. S. (2012). Human sulfide: quinone oxidoreductase catalyzes the first step in hydrogen sulfide metabolism and produces a sulfane sulfur metabolite. Biochemistry 51, 6804-6815. doi: 10.1021/ bi300778t

Jackson-Weaver, O., Osmond, J. M., Riddle, M. A., Naik, J. S., Gonzalez Bosc, L. V., Walker, B. R., et al. (2013). Hydrogen sulfide dilates rat mesenteric arteries by activating endothelial large-conductance $\mathrm{Ca}^{2+}$-activated $\mathrm{K}^{+}$channels and smooth muscle $\mathrm{Ca}^{2+}$ sparks. Am. J. Physiol. Heart Circ. Physiol. 304, H1446-H1454. doi: 10.1152/ajpheart.00506.2012

Kang, J., Li, Z., Organ, C. L., Park, C. M., Yang, C. T., Pacheco, A., et al. (2016). pH-Controlled hydrogen sulfide release for myocardial ischemiareperfusion injury. J. Am. Chem. Soc. 138, 6336-6339. doi: 10.1021/jacs. $6 \mathrm{~b} 01373$

Kimura, Y., Goto, Y., and Kimura, H. (2010). Hydrogen sulfide increases glutathione production and suppresses oxidative stress in mitochondria. Antioxid. Redox Signal. 12, 1-13. doi: 10.1089/ars.2008.2282

Kimura, Y., and Kimura, H. (2004). Hydrogen sulfide protects neurons from oxidative stress. FASEB J. 18, 1165-1167. doi: 10.1096/fj.04-1815fje

King, A. L., and Lefer, D. J. (2011). Cytoprotective actions of hydrogen sulfide in ischaemia-reperfusion injury. Exp. Physiol. 96, 840-846. doi: 10.1113/ expphysiol.2011.059725

King, B. S. (2013). Potential biological chemistry of hydrogen sulfide $\left(\mathrm{H}_{2} \mathrm{~S}\right)$ with the nitrogen oxides. Free Radic. Biol. Med. 55, 1-7. doi: 10.1016/j.freeradbiomed. 2012.11.005

Köhn, C., Dubrovska, G., Huang, Y., and Gollasch, M. (2012). Hydrogen sulfide: potent regulator of vascular tone and stimulator of angiogenesis. Int. J. Biomed. Sci. 8, 81-86.

Kolluru, G. K., Shen, X., Bir, S. C., and Kevil, C. G. (2013). Hydrogen sulfide chemical biology: pathophysiological roles and detection. Nitric Oxide 35, 5-20. doi: 10.1016/j.niox.2013.07.002

Lee, Z. W., Teo, X. Y., Tay, E. Y. W., Tan, C. H., Hagen, T., Moore, P. K., et al. (2014). Utilizing hydrogen sulfide as a novel anti-cancer agent by 
targeting cancer glycolysis and pH imbalance. Br. J. Pharmacol. 171, 4322-4336. doi: $10.1111 /$ bph. 12773

Lee, Z. W., Zhou, J., Chen, C. S., Zhao, Y., Tan, C. H., Li, L., et al. (2011). The slowreleasing hydrogen sulfide donor, GYY4137, Exhibits novel anti-cancer effects in vitro and in vivo. PLoS ONE 6:e21077. doi: 10.1371/journal.pone.0021077

Li, H., Ma, Y., Escaffre, O., Ivanciuc, T., Komaravelli, N., Kelley, J. P., et al. (2015). Role of hydrogen sulfide in paramyxovirus infections. J. Virol. 89, 5557-5568. doi: 10.1128/JVI.00264-15

Li, L., and Moore, P. K. (2011). Hydrogen sulfide and cell signaling. Annu. Rev. Pharmacol. Toxicol. 51, 169-187. doi: 10.1146/annurev-pharmtox-010510100505

Li, L., Salto-Tellez, M., Tan, C. H., Whiteman, M., and Moore, P. K. (2009). GYY4137, a novel hydrogen sulfide-releasing molecule, protects against endotoxic shock in rat. Free Radic. Biol. Med. 47, 103-113. doi: 10.1016/j. freeradbiomed.2009.04.014

Li, L., Whiteman, M., Guan, Y. Y., Neo, K. L., Cheng, Y., Lee, S. W., et al. (2008). Characterization of a novel, water-soluble hydrogen sulfide-releasing molecule (GYY4137). Circulation 117, 2351-2360. doi: 10.1161/CIRCULATIONAHA. 107.753467

Libiad, M., Yadav, P. K., Vitvitsky, V., Martinov, M., and Banerjee, R. (2014). Organization of the human mitochondrial hydrogen sulfide oxidation pathway. J. Biol. Chem. 289, 30901-30910. doi: 10.1074/jbc.M114.602664

Liu, D. K., and Chang, S. G. (1987). Kinetic study of the reaction between cystine and sulfide in alkaline solutions. Can. J. Chem. 65, 770-774. doi: 10.1139/ v87-131

Lu, S., Gao, Y., Huang, X., and Wang, X. (2014). GYY4137, a hydrogen sulfide $\left(\mathrm{H}_{2} \mathrm{~S}\right)$ donor, shows potent anti-hepatocellular carcinoma activity through blocking the STAT3 pathway. Int. J. Oncol. 44, 1259-1267. doi: 10.3892/ijo.2014. 2305

Medeiros, J. V., Bezerra, V. H., Gomes, A. S., Barbosa, A. L., Lima-Junior, R. C., Soares, P. M., et al. (2009). Hydrogen sulfide prevents ethanol-induced gastric damage in mice: role of ATP-sensitive potassium channels and capsaicinsensitive primary afferent neurons. J. Pharmacol. Exp. Ther. 330, 764-770. doi: 10.1124/jpet.109.152801

Mishanina, T. V., Yadav, P. K., Ballou, D. P., and Banerjee, R. (2015). Transient kinetic analysis of hydrogen sulfide oxidation catalyzed by human sulfide quinone oxidoreductase. J. Biol. Chem. 290, 25072-25080. doi: 10.1074/jbc. M115.682369

Nicolau, L. A., Silva, R. O., Damasceno, S. R., Carvalho, N. S., Costa, N. R., Aragao, K. S., et al. (2013). The hydrogen sulfide donor, Lawesson's reagent, prevents alendronate-induced gastric damage in rats. Braz. J. Med. Biol. Res. 46, 708-714. doi: 10.1590/1414-431X20133030

Olson, K. R. (2012). A practical look at the chemistry and biology of hydrogen sulfide. Antioxid. Redox Signal. 17, 32-44. doi: 10.1089/ars.2011.4401

Ozturk, T., Ertas, E., and Mert, O. (2007). Use of Lawesson's reagent in organic syntheses. Chem. Rev. 107, 5210-5278. doi: 10.1021/cr040650b

Pan, J., and Carroll, K. S. (2013). Persulfide reactivity in the detection of protein S-sulfhydration. ACS Chem. Biol. 8, 1110-1116. doi: 10.1021/cb4001052

Park, C. M., Zhao, Y., Zhu, Z., Pacheco, A., Peng, B., Devarie-Baez, N. O., et al. (2013). Synthesis and evaluation of phosphorodithioate-based hydrogen sulfide donors. Mol. Biosyst. 9, 2430-2434. doi: 10.1039/c3mb70145j

Paul, B. D., and Snyder, S. H. (2012). $\mathrm{H}_{2} \mathrm{~S}$ signaling through protein sulfhydration and beyond. Nat. Rev. Mol. Cell. Biol. 13, 499-507. doi: 10.1038/nrm3391

Paulsen, C. E., and Carroll, K. S. (2013). Cysteine-mediated redox signaling: chemistry, biology, and tools for discovery. Chem. Rev. 113, 4633-4679. doi: $10.1021 / \mathrm{cr} 300163 \mathrm{e}$

Pietri, R., Lewis, A., Leon, R. G., Casabona, G., Kiger, L., Yeh, S. R., et al. (2009). Factors controlling the reactivity of hydrogen sulfide with hemeproteins. Biochemistry 48, 4881-4894. doi: 10.1021/bi801738j

Predmore, B. L., Lefer, D. J., and Gojon, G. (2012). Hydrogen sulfide in biochemistry and medicine. Antioxid. Redox Signal. 17, 119-140. doi: 10.1089/ ars. 2012.4612

Szabo, C., Ransy, C., Módis, K., Andrianmihaja, M., Murghes, B., Coletta, C., et al. (2014). Regulation of mitochondrial bioenergetic function by hydrogen sulfide. Part I. Biochemical and physiological mechanisms. Br. J. Pharmacol. 171, 2099-2122. doi: 10.1111/bph.12369

Vadivel, A., Alphonse, R. S., Ionescu, L., Machado, D. S., O’Reilly, M., Eaton, F., et al. (2014). Exogenous hydrogen sulfide $\left(\mathrm{H}_{2} \mathrm{~S}\right)$ protects alveolar growth in experimental $\mathrm{O}_{2}$-induced neonatal lung injury. PLoS ONE 9:e90965. doi: 10.1371/journal.pone.0090965

Vandiver, M. S., Paul, B. D., Xu, R., Karuppagounder, S., Rao, F., Snowman, A. M., et al. (2013). Sulfhydration mediates neuroprotective actions of parkin. Nat. Commun. 4:1626. doi: 10.1038/ncomms2623

Vasas, A., Dóka, É., Fábián, I., and Nagy, P. (2015). Kinetic and thermodynamic studies on the disulfide-bond reducing potential of hydrogen sulfide. Nitric Oxide 46, 93-101. doi: 10.1016/j.niox.2014.12.003

Wallace, J. L., Vong, L., McKnight, W., Dicay, M., and Martin, G. R. (2009). Endogenous and exogenous hydrogen sulfide promotes resolution of colitis in rats. Gastroenterology 137, 569-578. doi: 10.1053/j.gastro.2009.04.012

Wang, R. (2012). Physiological implications of hydrogen sulfide: a whiff exploration that blossomed. Physiol. Rev. 92, 791-896. doi: 10.1152/physrev. 00017.2011

Wei, W. B., Hu, X., Zhuang, X. D., Liao, L. Z., and Li, W. D. (2014). GYY ${ }_{4137}$, a novel hydrogen sulfide-releasing molecule, likely protects against high glucoseinduced cytotoxicity by activation of the AMPT/mTOR signal pathway in $\mathrm{H}_{9 \mathrm{c} 2}$ cells. Mol. Cell. Biochem. 389, 249-256. doi: 10.1007/s11010-013-1946-6

Wen, Y. D., Wang, H., Kho, S. H., Rinkiko, S., Sheng, X., Shen, H. M., et al. (2013). Hydrogen sulfide protects HUVECs against hydrogen peroxide induced mitochondrial dysfunction and oxidative stress. PLOS ONE 8:e53147. doi: 10.1371/journal.pone.0053147

Whiteman, M., Le Trionnaire, S., Chopra, M., Fox, B., and Whatmore, J. (2011). Emerging role of hydrogen sulfide in health and disease: critical appraisal of biomarkers and pharmacological tools. Clin. Sci. 121, 459-488. doi: 10.1042/ CS20110267

Whiteman, M., Li, L., Rose, P., Tan, C. H., Parkinson, D. B., and Moore, P. K. (2010). The effect of hydrogen sulfide donors on lipopolysaccharide-induced formation of inflammatory mediators in macrophages. Antioxid. Redox Signal. 12, 1147-1154. doi: 10.1089/ars.2009.2899

Wu, J., Li, Y., He, C., Kang, J., Ye, J., Xiao, Z., et al. (2016). Novel $\mathrm{H}_{2} \mathrm{~S}$ releasing nanofibrous coating for in vivo dermal wound regeneration. ACS Appl. Mater. Interfaces 8, 27474-27481. doi: 10.1021/acsami.6b06466

Wu, Z., Peng, H., Du, Q., Lin, W., and Liu, Y. (2015). GYY4137, a hydrogen sulfide-releasing molecule, inhibits the inflammatory response by suppressing the activation of nuclear factor-kappa B and mitogen-activated protein kinases I coxsackie virus B3 infected rat cardiomyocytes. Mol. Med. Rep. 11, 1837-1844.

Xue, R., Hao, D., Sun, J., Li, W., Zhao, M., Li, X., et al. (2013). Hydrogen sulfide treatment promotes glucose uptake by increasing insulin receptor sensitivity and ameliorates kidney lesions in type 2 diabetes. Antioxid. Redox Signal. 19, 5-23. doi: 10.1089/ars.2012.5024

Yang, C., Lai, Z., Zheng, Z., Kang, J., Xian, M., Wang, R., et al. (2017). A novel $\mathrm{pH}$-controlled hydrogen sulfide donor protects gastric mucosa from aspirininduced injury. J. Cell. Mol. Med. doi: 10.1111/jcmm.13166 [Epub ahead of print].

Yang, G., Zhao, K., Ju, Y., Mani, S., Cao, Q., Puukila, S., et al. (2013). Hydrogen sulfide protects against cellular senescence via S-sulfhydration of Keap1 and activation of Nrf2. Antioxid. Redox Signal. 18, 1906-1919. doi: 10.1089/ars.2012. 4645

Zanardo, R. C., Brancaleone, V., Distrutti, E., Fiorucci, S., Cirino, G., and Wallace, J. L. (2006). Hydrogen sulfide is an endogenous modulator of leukocytemediated inflammation. FASEB J. 20, 2118-2120. doi: 10.1096/fj.06-6270fje

Zhang, D., Macinkovic, I., Devarie-Baez, N. O., Pan, J., Park, C. M., Carroll, K. S., et al. (2014). Detection of protein S-sulfhydration by a tag-switch technique. Angew. Chem. Int. Ed. 53, 575-581. doi: 10.1002/anie.201305876

Zhang, Q., Fu, H., Zhang, H., Xu, F., Zou, Z., Liu, M., et al. (2013). Hydrogen sulfide preconditioning protects rat liver against ischemia/reperfusion injury by activating Akt-GSK-3( $\beta$ signaling and inhibiting mitochondrial permeability transition. PLoS ONE 8:e74422. doi: 10.1371/journal.pone.0074422

Zhao, W. M., Zhang, J., Lu, Y. J., and Wang, R. (2001). The vasorelaxant effect of $\mathrm{H}_{2} \mathrm{~S}$ as a novel endogenous gaseous $\mathrm{K}_{\mathrm{ATP}}$ channel opener. EMBO J. 20, 6008-6016. doi: 10.1093/emboj/20.21.6008

Zhao, Y., Bhushan, S., Yang, C., Otsuka, H., Stein, J. D., Pacheco, A., et al. (2013). Controllable hydrogen sulfide donors and their activity against myocardial ischemia-reperfusion injury. ACS Chem. Biol. 8, 1283-1290. doi: 10.1021/ cb400090d

Zhao, Y., Kang, J., Park, C. M., Bagdon, P. E., Peng, B., and Xian, M. (2014). Thiol-activated gem-dithiols: a new class of controllable hydrogen 
sulfide $\left(\mathrm{H}_{2} \mathrm{~S}\right)$ donors. Org. Lett. 16, 4536-4539. doi: 10.1021/ol5 $02088 \mathrm{~m}$

Zhao, Y., Pacheco, A., and Xian, M. (2015). Medicinal chemistry: insights into the development of novel $\mathrm{H}_{2} \mathrm{~S}$ donors. Handb. Exp. Pharmacol. 230, 365-388. doi: 10.1007/978-3-319-18144-8_18

Zhao, Y., Wang, H., and Xian, M. (2011). Cysteine-activated hydrogen sulfide $\left(\mathrm{H}_{2} \mathrm{~S}\right)$ donors. J. Am. Chem. Soc. 133, 15-17. doi: 10.1021/ja1085723

Zheng, Y., Yu, B., De La Cruz, L. K., Choudhury, M. R., Anifowose, A., and Wang, B. (2017). Toward hydrogen sulfide based therapeutics: critical drug delivery and developability issues. Med. Res. Rev. doi: 10.1002/med.21433 [Epub ahead of print].
Conflict of Interest Statement: The authors declare that the research was conducted in the absence of any commercial or financial relationships that could be construed as a potential conflict of interest.

Copyright (c) 2017 Kang, Neill and Xian. This is an open-access article distributed under the terms of the Creative Commons Attribution License (CC BY). The use, distribution or reproduction in other forums is permitted, provided the original author(s) or licensor are credited and that the original publication in this journal is cited, in accordance with accepted academic practice. No use, distribution or reproduction is permitted which does not comply with these terms. 